\title{
Osseous metaplasia in gliosarcoma: an unusual histologic finding. Case report
}

\author{
Metaplasia óssea no gliossarcoma: um achado histológico pouco usual. Relato de caso
}

Eduardo Cambruzzi'; Karla Lais Pêgas ${ }^{2}$

\begin{abstract}
Gliosarcoma (GS) is a malignant neoplasm of the central nervous system that has coexisting glial and mesenchymal components. GSs are rarely related to osseous metaplasia. The authors report a case of GS in a male patient presenting apathy and catatonia. Computed tomography/magnetic resonance imaging showed an expansive process affecting the left frontal lobe. At microscopy, a malignant glioma constituted by highly atypical glial cells intermingled with spindle-shaped cells was identified. The lesion showed areas of necrosis with pseudopalisading formation, focus of osseous metaplasia, and positive immunoexpression of S100, CD99 and vimentin in both elements. Only the sarcomatous component exhibited negative immunoexpression of glial fibrillary acidic protein (GFAP). The diagnosis of GS was then established.
\end{abstract}

Key words: gliosarcoma; central nervous system neoplasms; pathology; brain neoplasms; glioblastoma.

\section{INTRODUCTION}

Gliosarcoma (GS) is actually considered a glioblastoma variant characterized by the coexistence of glial and mesenchymal components. GS (World Health Organization [WHO] grade IV) constitutes approximately $2 \%-4 \%$ of all cases of glioblastoma. Males are more frequently affected, with general clinical manifestation between 40 and 60 years of age. GS usually involves the cerebral hemispheres, with rare cases arising in the posterior fossa and the spinal cord. The sarcomatous element is a spindlecell proliferation that usually has the classic herringbone pattern of fibrosarcoma. Occurrence of osseous tissue in GS is an unusual finding ${ }^{(4,6,11,13,15)}$. Herein the authors report a case of GS with osseous metaplasia, and discuss pathological and clinical findings of this tumor.

\section{CASE REPORT}

Male patient, 56 years old, was taken to the neurology service presenting episodes of apathy and catatonia in the previous 30 days. On physical examination, the patient did not exhibit focal neurological deficits. The other organs and systems did not show clinical alterations, as there was no previous history of relevant disease. Computed tomography (CT) and magnetic resonance imaging (MRI) revealed a large heterogeneous expansive process affecting the left frontal lobe, with midline shift (Figure 1). CT/MRI of the chest and abdomen did not identify significant alterations. The patient underwent resection of the lesion. On gross examination, the sample was composed of gray, irregular fragments, which weighed $61 \mathrm{~g}$. The largest fragment measured $7.3 \times 5.5 \times 4.6 \mathrm{~cm}$. At microscopy, a biphasic central nervous system (CNS) neoplasm was identified. The process consisted of

First submission on $05 / 09 / 13$; last submission on $06 / 11 / 13$; accepted for publication on $06 / 11 / 13$; published on 20/02/14

1. Post-doctorate in Cardiovascular Pathology from Instituto de Cardiologia do Rio Grande do Sul; assistant professor of Histology and Pathology at Universidade Federal do Rio Grande do Sul (UFRGS).

2. Master's degree in Pathology from Universidade Federal de Ciências da Saúde de Porto Alegre (UFCSPA); medical pathologist at Irmandade da Santa Casa de Misericórdia de Porto Alegre. 
glial elements and spindle-shaped cells, which were distributed in a predominantly solid pattern. The glial component was constituted by highly atypical astrocytes, with pleomorphic nuclei, zones of necrosis with formation of pseudopalisading, microvascular proliferation and high mitotic index (Figure 2). The spindleshaped cells showed moderate nuclear pleomorphism, areas of necrosis, and a high mitotic index (Figure 3). The mesenchymal component showed positive stains for reticulin, and focal formation of benign osteoid tissue (Figure 4). The glial component showed positive immunoexpression of glial fibrillary acidic protein (GFAP), S100, vimentin and anti-neuron specific enolase (NSE). The mesenchymal component was immunoreactive for S100
(Figure 5), CD99 (MIC2) and vimentin, especially around vessels, and showed negative immunoexpression of GFAP and NSE. The sarcomatous component showed positive stains for Ki-67 antigen in 30\% of the cells. All neoplastic cells exhibited negative immunoexpression of $\operatorname{CD} 68$, cytokeratin 7, epithelial membrane antigen (EMA), human melanoma black-45 (HMB45), podoplamin, and progesterone receptor. The diagnosis of GS with zones of osseous metaplasia was then established. The patient was referred to radiotherapy, but tumor recurrence was identified on MRI scan three months after the surgical procedure. At that moment, the patient died due to a sudden onset of intracranial hypertension.
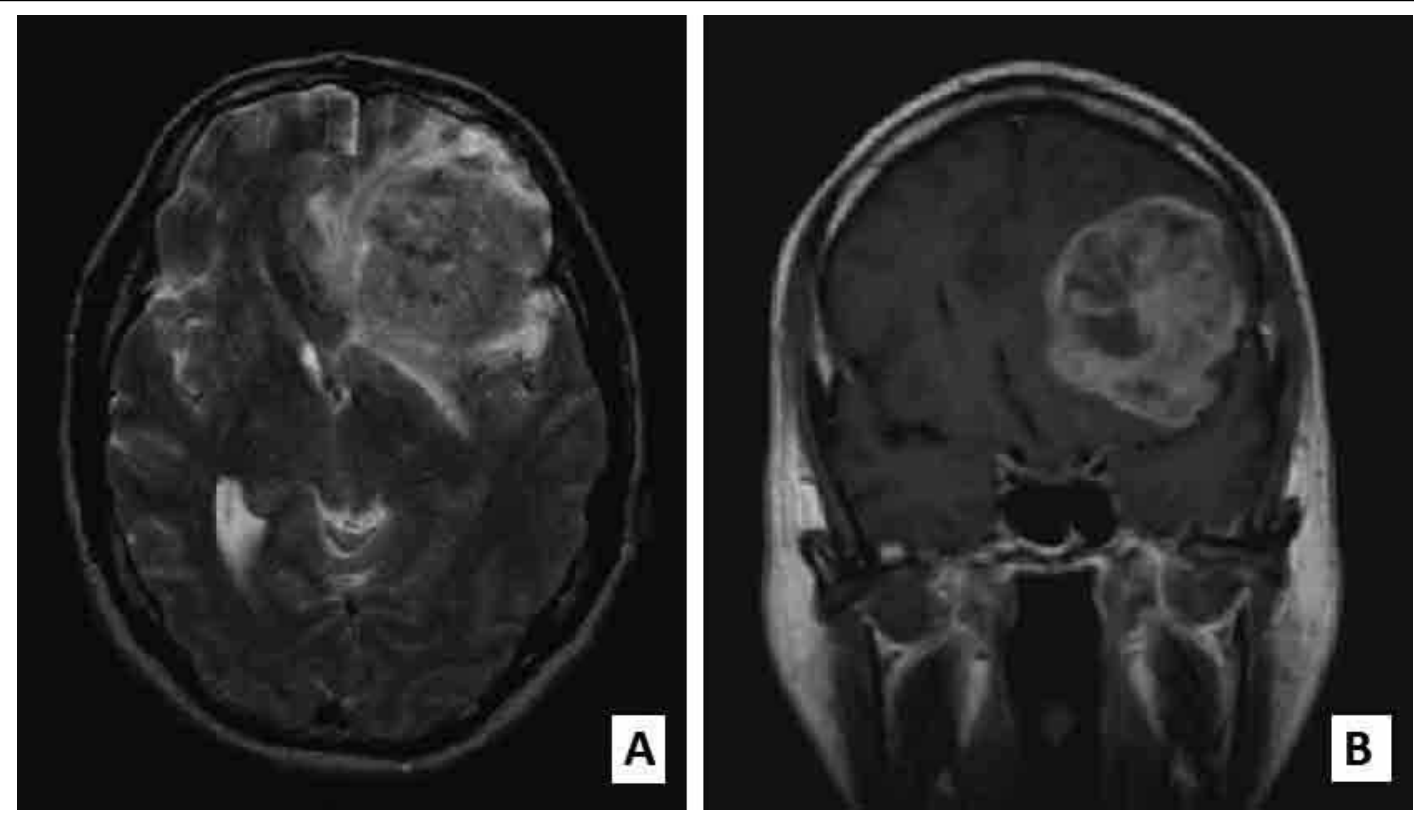

FIGURE 1 -T2-weighted (A) and postcontrast T1-weighted (B) MRI showing an expansive bulky lesion arising in the left frontal lobe, with an irregular ring contrast enhancement

MRI: magnetic resonance imaging.

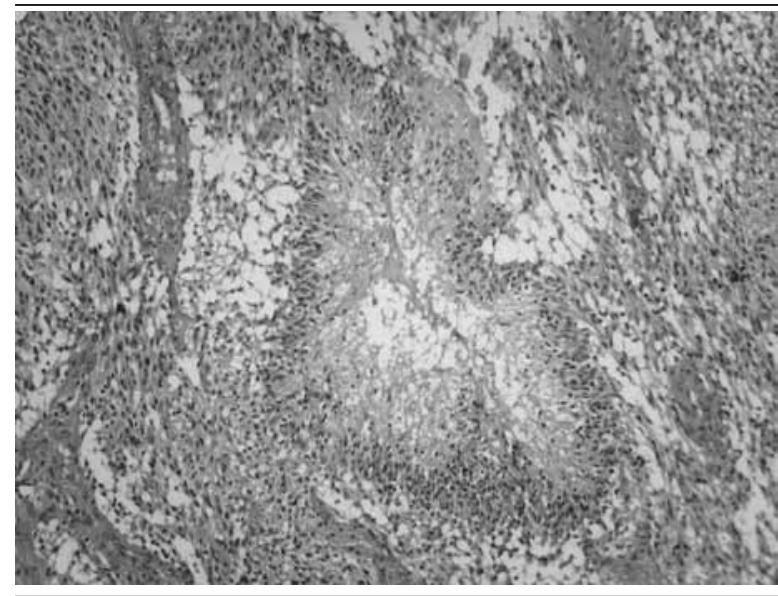

FIGURE 2 - A classic pattern of glioblastoma: palisading around zones of necrosis (HEE, 100×)

HEE: bematoxylin and eosin



FIGURE 3 -Gliosarcoma: the sarcomatous element is a spindle-cell proliferation distributed in disorganized fascicles (HEE, 100×)

HEE: hematoxylin and eosin 


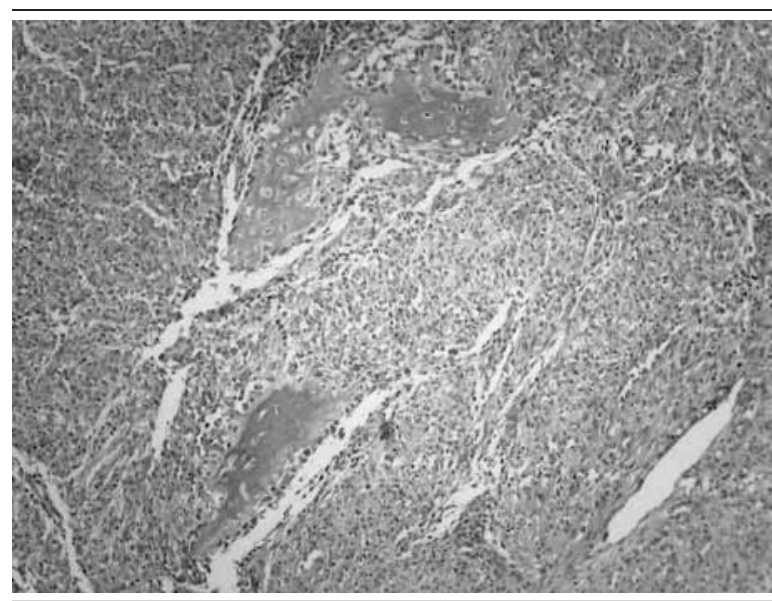

FIGURE 4 -Gliosarcoma: occasional areas of osseous metaplasia (HEE 100×) HEE: hematoxylin and eosin.
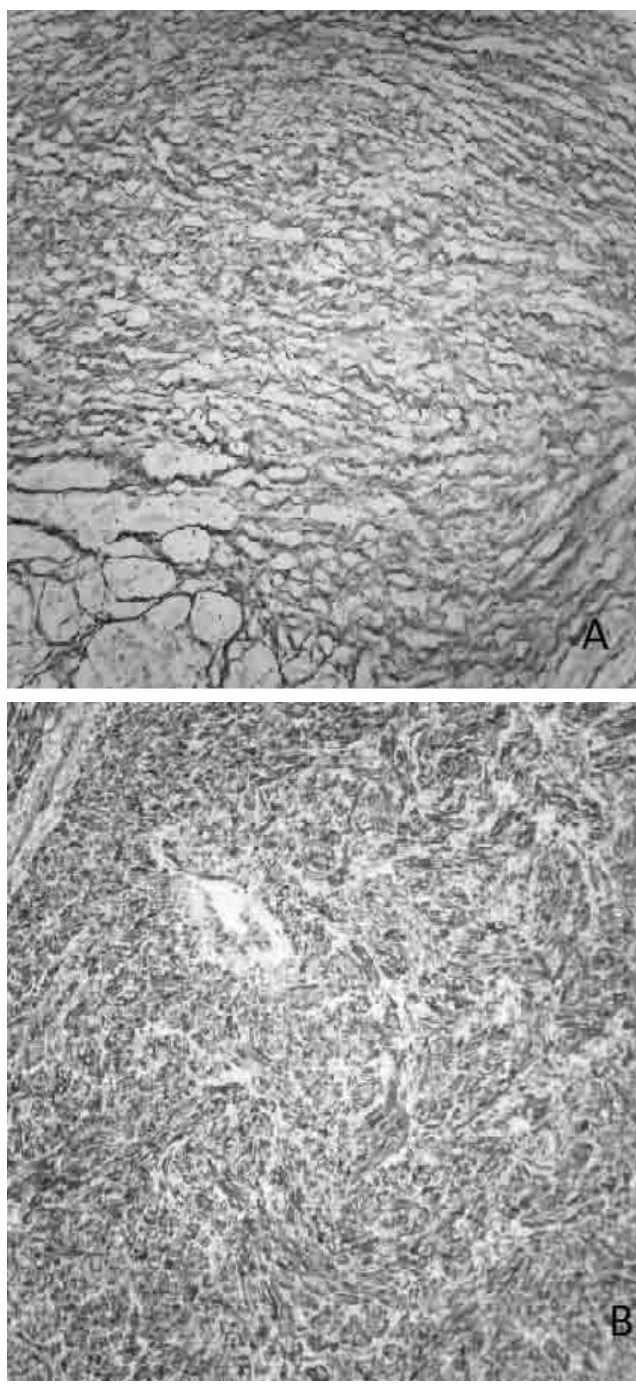

FIGURE 5 - Gliosarcoma

A: pericellular reticulin was abundant in mesenchymal areas, but absent in the glial element (reticulin, 200×); B: positive immunoexpression for $\$ 100$ in mesenchymal area (streptavidin-biotin, 100×).

\section{DISCUSSION}

GS is usually located, in decreasing order of frequency, in the temporal (44\%), frontal (30\%), parietal (28\%) and occipital lobes (11\%), with rare cases affecting the cerebellum and the spinal cord. Unusual cases have been related to systemic metastases. Clinically, GS can be associated with a short history of seizures, focal neurological signs, or increased intracranial pressure. Most tumors arise in the absence of recognized predisposing factors. Eventually, radiotherapy may be associated with GS development in a recurrent ordinary glioblastoma. GS is a rapidly enlarging, anaplastic tumor that can eventually show ring enhancement on postcontrast CT/MRI scans similarly to ordinary glioblastoma, or can mimic a metastatic lesion. Occasional cases are so attached to the dura that the process can resemble a large meningioma ${ }^{(2,4-8,10-15,20,25)}$.

On gross examination, GS is more frequently a firm, wellcircumscribed single mass, due to its high content of connective tissues. This appearance can also be mistaken for a metastatic process, or for a meningioma, if attached to the dura. Lesions related to sparse connective tissue may resemble a glioblastoma, including yellow central areas of necrosis.

At microscopy, the hallmark of GS is the mixture of gliomatous and sarcomatous elements. The glial component shows astrocytic differentiation, with anaplastic features resembling a glioblastoma. Occasionally, the glial component is inconspicuous, and can be found as clusters or even single cells between the mesenchymal elements. The sarcomatous component exhibits nuclear atypia, mitotic activity and necrosis. GS frequently shows the herringbone pattern of fibrosarcoma. Some cases demonstrate the disorganized fascicles and cellular pleomorphism of a malignant fibrous histiocytoma. In other lesions, the mesenchymal element is topographically associated with blood vessels, and appears to merge within proliferating vascular or adventitial tissue. Additional lines of mesenchymal differentiation can be found, including bone, epithelium, smooth muscle, and striated muscle. Reticulin and trichrome stain can highlight the mesenchymal component. Multiple forms of mesenchyme may coexist in the same process. The sarcomatous areas show negative immunoexpression of GFAP, which is characteristically expressed in the glial component. The finding of S100 protein and even GFAP positivity in the sarcomatous element, associated with molecular data, support the hypothesis that the mesenchymal neoplastic cells result from a metaplastic transformation of the glial neoplastic cells. Immunoreactivity for p53 and cytokeratins is found in some cases of $\mathrm{GS}^{(2,4-8,10-15,20,25)}$.

Tyagi et al. reported a case of GS in a male patient who presented episodes of dizziness and seizures for six months. These 
authors described the formation of benign osteoid tissue rimmed by osteoblasts in the sarcomatous element. There were also focal areas of chondroid metaplasia in this case ${ }^{(24)}$. Charfi et al. report a case of gliosarcoma with osteosarcomatous features in a 33-year- old woman. Histologically, the sarcomatous portion displayed a typical pattern of fibrosarcoma associated with areas of osteoid formation ${ }^{(5)}$. The Table shows some cases of GS found in the international literature and comparable to the reported case.

TABLE - Summary of some published cases of gliosarcoma

\begin{tabular}{|c|c|c|c|c|c|}
\hline Authors & Age/gender & Clinical findings & Topography & Treatment modality & Outcome \\
\hline Andaloussi-Saghir et al. ${ }^{(2)}$ & 48 years/M & $\begin{array}{l}\text { Dizziness } \\
\text { Headache } \\
\text { Seizures }\end{array}$ & Temporal lobe & $\begin{array}{l}\text { Surgery + radiotherapy } \\
+ \text { chemotherapy }\end{array}$ & $\begin{array}{l}\text { Died after } 27 \text { months due } \\
\text { to tumor recurrence }\end{array}$ \\
\hline Chen et al. ${ }^{(6)}$ & 31 years/F & $\begin{array}{l}\text { Dizziness } \\
\text { Headache } \\
\text { Vomiting }\end{array}$ & Cerebrum & $\begin{array}{l}\text { Surgery + radiotherapy } \\
\quad+\text { chemotherapy }\end{array}$ & $\begin{array}{l}\text { Developed metastases to } \\
\text { liver, lymph nodes, skeleta } \\
\text { and spinal cord }\end{array}$ \\
\hline Demirci et $a l^{(8)}$ & 68 years/F & $\begin{array}{l}\text { Headache } \\
\text { Hemiplegia }\end{array}$ & Cerebrum & $\begin{array}{c}\text { Surgery + } \\
\text { radiotherapy }\end{array}$ & $\begin{array}{l}\text { Developed metastasis to } \\
\text { the thoracic spinal cord }\end{array}$ \\
\hline Jimenez et $a l .{ }^{(9)}$ & 65 years/F & $\begin{array}{c}\text { Weakness } \\
\text { Seizures } \\
\text { Hemiparesis }\end{array}$ & Frontal lobe & Surgery & Unavailable \\
\hline Maeda et al. ${ }^{(12)}$ & 51 years/F & Headache & Temporal lobe & Surgery & Developed lung metastasis \\
\hline Mesfin et al. ${ }^{(14)}$ & 51 years/F & $\begin{array}{c}\text { Generalized tonic- } \\
\text { clonic seizures }\end{array}$ & Temporal lobe & $\begin{array}{c}\text { Surgery + radiotherapy } \\
+ \text { chemotherapy }\end{array}$ & $\begin{array}{c}\text { Developed lung } \\
\text { metastasis }\end{array}$ \\
\hline Moon et al..$^{(15)}$ & 70 years/ $\mathrm{F}$ & Headache & Cerebellum & Surgery & Unavailable \\
\hline Neelima et al. ${ }^{(17)}$ & 11 years/M & $\begin{array}{l}\text { Headache } \\
\text { Vomiting }\end{array}$ & Thalamus & Surgery & Unavailable \\
\hline Okami et al. ${ }^{(18)}$ & 23 months/M & $\begin{array}{l}\text { Headache } \\
\text { Vomiting }\end{array}$ & Frontal lobe & Surgery & $\begin{array}{l}\text { Died } 2 \text { months } \\
\text { after surgery }\end{array}$ \\
\hline Ravisankar et al. . (21) & 11 years/M & $\begin{array}{l}\text { Headache } \\
\text { Vomiting }\end{array}$ & $\begin{array}{c}\text { Temporo- } \\
\text { parietal region }\end{array}$ & $\begin{array}{l}\text { Surgery + radiotherapy } \\
\quad+\text { chemotherapy }\end{array}$ & Unavailable \\
\hline Sarkar et al. . 22$)$ & 60 years/F & $\begin{array}{c}\text { Headache } \\
\text { Vomiting } \\
\text { Intracranial } \\
\text { hypertension }\end{array}$ & $\begin{array}{l}\text { Septal region and } \\
\text { body/frontal horn of } \\
\text { the lateral ventricles }\end{array}$ & $\begin{array}{c}\text { Surgery }+ \\
\text { chemotherapy }\end{array}$ & Unavailable \\
\hline Present report & 56 years/M & Abulia and catatonia & Frontal lobe & Surgery & $\begin{array}{l}\text { Died } 3 \text { months } \\
\text { after surgery }\end{array}$ \\
\hline
\end{tabular}

M: male; F: female

Recent studies have shown that both glial and mesenchymal components of GS share cytogenetic abnormalities or an identical p53 mutation. These findings suggest that the malignant mesenchymal component appears to be the result of a pseudosarcomatous metaplasia within the proliferative glial cells, or the transformation of mesenchymal elements belonging to the proliferative vascular stroma of a glioblastoma. The histogenesis of the osseous element in GS can be associated with 
a metaplastic transformation or a divergent differentiation from a common progenitor cell. The osseous component in GS can be found like newly formed osteoid, bony trabeculae with osteoblastic rimming, or malignant tissue resembling osteosarcoma. In spite of this highly atypical phenotype, GS has the same prognosis as usual glioblastoma. A comparative genomic hybridization study has demonstrated shared genetic abnormalities between glial and mesenchymal cells, but also evidence of progression in the sarcomatous components. GS demonstrate phosphatase and tensin homolog (PTEN) mutations, p16 $6^{\text {INKa }}$ deletions and tumor protein p53 (TP53) mutations. Epidermal growth factor receptor (EGFR) amplifications, which are frequent in glioblastoma, are

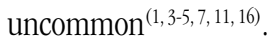

Differential diagnosis includes glioblastoma exhibiting intense desmoplasia, the very rare primary CNS sarcomas, like fibrosarcoma and angiosarcoma, metastatic sarcomas, and malignant meningioma. Desmoplastic malignant glioma (DMG) shows a mesenchymal component that is not always clearly neoplastic, and has a cicatricial pattern in some areas. Except around vessels, vascular proliferation, necrosis, mitotic activity, and nuclear atypia are uncommon in collagen-rich zones of DMG. Clinical data and an extensive immunohistochemical panel, including CD34, CD31, alpha-smooth muscle actin, desmin, and myogenin, are necessary to evaluate sarcomas, which exhibit negative immunoexpression of GFAP. Cytokeratins AE1/AE3, CK7, CK20, carcinoembryonic antigen (CEA), and EMA are useful antibodies to exclude metastatic carcinomas and meningiomas. Pericellular reticulin, virtually a defining feature of fibrosarcoma, is generally absent in malignant meningioma. In infants, desmoplastic infantile ganglioglioma, superficial desmoplastic infantile astrocytoma and desmoplastic cerebral astrocytoma (DCA) of infancy must be considered. All these lesions are typically large cystic tumors of infants and have a good prognosis after surgical resection. These tumors usually show positive expression for GFAP by spindle-shaped astrocytes. In these lesions, negative expression for GFAP can be found in many spindle cells that only express vimentin, what suggests a fibroblastic phenotype. Ganglion cells and polygonal neuronal cells may show synaptophysin, neurofilament protein, and tubulin immunoexpression. Gliofibroma is a very rare tumor that can affect children. In contrast to DCA, gliofibroma is a biphasic solid tumor constituted by a glial component that ranges from low- to high-grade lesion, and a non-sarcomatous fibroblastic component. Gliofibroma has a favorable prognosis, and rarely the tumor shows areas of necrosis, vascular proliferation, hypercellularity, nuclear pleomorphism and high mitotic index ${ }^{(2-4,7,710,11,13,14,17-19,21-23)}$.

GS has a poor prognosis, with a mean survival of less than one year. The outcome of GS depends largely upon the stage at which it is diagnosed, the site of the tumor, and age. Surgical excision, radiotherapy and chemotherapy may increase the quality of life for the patient ${ }^{(4,6,8,10,11,14,15,17,20)}$.

\section{RESUMO}

Gliossarcoma (GS) é uma neoplasia maligna do sistema nervoso central que apresenta coexistência de componentes glial e mesenquimal. Raramente, os GS estão associados à metaplasia óssea. Os autores descrevem um caso de GS em paciente masculino apresentando apatia e catatonia. A tomografia computadorizada e a ressonância magnética mostraram um processo expansivo comprometendo o lobo frontal esquerdo. À microscopia, foi identificado um glioma maligno constituído por células gliais extremamente atípicas entremeadas com células fusiformes. A lesão mostrava áreas de necrose com formação depseudopaliçada, focos de metaplasia óssea e expressão imuno-bistoquímica positiva para S100, CD99 e vimentina em ambos os componentes. Somente o componente sarcomatoso exibiu imunoexpressão negativa para proteína glial fibrilar ácida (GFAP). 0 diagnóstico de GS foi, então, estabelecido.

Unitermos: gliossarcoma; neoplasias do sistema nervoso central; patologia; neoplasias encefálicas; glioblastoma.

\section{REFERENCES}

1. ACTOR, B. et al. Comprehensive analysis of genomic alterations in gliosarcoma and its two tissue components. Genes Chromosomes Cancer, v. 34, n. 4, p. 416-27, 2002.
2. ANDALOUSSI-SAGHIR, K. et al. Secondary gliosarcoma after the treatment of primary glioblastoma multiforme. $N$ Am J Med Sci, v. 3 , n. 11, p. 527-30, 2011.

3. BOERMAN, R. H. et al. The glial and mesenchymal elements of gliosarcomas share similar genetic alterations. I Neuropathol Exp Neurol, v. 55, n. 9, p. 973-81, 1996. 
4. BURGER, P. C., SCHEITHAUER, B. W. Gliosarcoma. In: BURGER, P. C., SCHEITHAUER, B. W. Tumors of the Central Nervous System (AFIP Atlas of Tumor Pathology). $4^{\text {th }}$ Series. Washington: ARP, 2007. p. 77-80.

5. CHARFI, S. et al. Gliosarcoma with osteosarcomatous features: a short illustrated review.Acta Neurochir (Wien), v. 151, n. 7, p. 809-13, 2009.

6. CHEN, L. et al. A case study of a patient with gliosarcoma with an extended survival and spinal cord metastases. Cell Biochem Biophys, v. 62, n. 2, p. 391-5, 2012.

7. DAHLBACK, H. S. et al. Molecular cytogenetic analysis of a gliosarcoma with osseous metaplasia. Cytogenet Genome Res, v. 134, n. 2, p. 88-95, 2011.

8. DEMIRCI, S. et al. Multiple spinal metastases of cranial gliosarcoma: a case report and review of the literature. J Neurooncol, v. 88, n. 2, p. 199-204, 2008.

9. JIMENEZ, C. et al. Sarcoma arising as a distinct nodule within glioblastoma: a morphological and molecular perspective on gliosarcoma. J Neurooncol, v. 105, n. 2, p. 317-23, 2011.

10. HAN, S. J.et al. Secondary gliosarcoma after diagnosis of glioblastoma: clinical experience with 30 consecutive patients. J Neurosurg, v. 112, n. 5, p. 990-6, 2010.

11. KLEIHUES, P. et al. Gliosarcoma. In: LOUIS, D. N. et al. WHO Classification of Tumours of the Central Nervous System. 3. ed. Lyon: IARC Press, 2007. p. 48-9.

12. MAEDA, D. et al. Temporal gliosarcoma with extraneural metastasis: case report. Neurol Med Chir (Tokyo), v. 50, n. 4, p. 343-5, 2010.

13. MCLENDON, R. E.; FRIEDMAN, A. H.; GRAY, L. Glioblastoma. In: MCLENDON, R. E.; ROSENBluM, M. K.; BIGNER, D. D. Russell E Rubinstein's Pathology of Tumors of the Nervous System. 7. ed. New York: Oxford University Press Inc, 2006. p. 103-24.
14. MESFIN, F. B. et al. Metastatic gliosarcoma with a unique presentation and progression: case report and review of the literature. Clin Neuropathol, v. 29, n. 3, p. 147-50, 2010.

15. MOON, S. K. et al. Gliosarcoma of the cerebellar hemisphere: a case report and review of the literature. Korean J Radiol, v. 11, n. 5, p. 566-70, 2010.

16. NAGAISHI, M. et al. Transcriptional factors for epithelialmesenchymal transition are associated with mesenchymal differentiation in gliosarcoma. Brain Pathol, v. 22, n. 5, p. 670-6, 2012.

17. NEELIMA, R. et al. Pediatric gliosarcoma of thalamus. Neurol India, v. 60, n. 6, p. 674-6, 2012.

18. OKAMI, N. et al. Infantile gliosarcoma: a case and a review of the literature. Childs Nerv Syst, v. 18, n. 6-7, p. 351-5, 2002.

19. OZOLEK, J. A. et al. Gliosarcoma with epithelial differentiation: immunohistochemical and molecular characterization. A case report and review of the literature. Mod Pathol, v. 17, n. 6, p. 739-45, 2004

20. PAREKH, H. C. et al. Primary cerebral gliosarcoma: report of 17 cases. Br J Neurosurg, v. 9, n. 2, p. 171-8, 1995.

21. RAVISANKAR, S. et al. Pediatric gliosarcoma with fibrosarcomatous differentiation: report of a rare case. Indian J Pathol Microbiol, v. 55, n. 4, p. 521-4, 2012

22. SARKAR, H. et al. Pure intraventricular origin of gliosarcoma - a rare entity. Turk Neurosur, v. 23, n. 3, p. 392-4, 2013.

23. SREENAN, J. J.; RAYSON, R. A. Gliosarcoma. A study of 13 tumors, including p53 and CD34 immunohistochemistry. Arch Pathol Lab Med, v. 121, n. 2, p. 129-33, 1997.

24. TYAGI, I. et al. Gliosarcoma with osseous tissue: an occasional metaplastic component. Brain Tumor Pathol, v. 30, n. 1, p. 40-4, 2013.

25. ZHANG, B. Y. et al. Computed tomography and magnetic resonance features of gliosarcoma: a study of 54 cases. J Comput Assist Tomogr, v. 35, n. 6, p. 667-73, 2011.

\section{MAILING ADDRESS}

\section{Eduardo Cambruzzi}

Hospital Conceição de Porto Alegre; Laboratório de Patologia B; Av. Francisco Trein, 596, $2^{\circ}$ andar; Cristo Redentor; CEP: 91350-200; Porto Alegre-RS, Brazil; e-mail: dudacambruzzi@yahoo.com.br. 